\title{
1 Challenges in predicting climate change impacts on pome fruit \\ 2 phenology
}

Rebecca Darbyshire $^{1^{*}}$, Leanne Webb ${ }^{2}$, Ian Goodwin ${ }^{3}$, E.W.R. Barlow ${ }^{1}$

${ }^{1}$ Melbourne School of Land and Environment, University of Melbourne, Victoria, Australia

${ }^{2}$ CSIRO Marine and Atmospheric Research, Victoria, Australia

${ }^{3}$ Victorian Department of Primary Industries, Tatura, Australia

*corresponding author: r.darbyshire@student.unimelb.edu.au

Ph: +61383449317

3

Fax: +61393494218

\section{Abstract}

5 Climate projection data were applied to two commonly used pome fruit flowering models to investigate potential differences in predicted full bloom timing. The two methods, fixed thermal time and sequential chill-growth, produced different results for seven apple and pear varieties at two Australian locations. The fixed thermal time model predicted incremental advancement of full bloom while results were mixed from the sequential chill-growth model. To further investigate how the sequential chill-growth model reacts under climate perturbed conditions, four simulations were created to represent a wider range of species physiological requirements. These were applied to five Australian locations covering varied climates. Lengthening of the chill period and contraction of the growth period was common to most results. The relative dominance of the chill or growth component tended to predict whether full bloom advanced, remained similar or was delayed with climate warming. The simplistic structure of the fixed thermal time model and the exclusion of winter chill conditions in this method indicate it is unlikely to be suitable for projection analyses. The sequential chill-growth model includes greater complexity, however reservations in using this model for impact analyses remain. The results demonstrate that appropriate representation of physiological processes is essential to adequately predict changes to full bloom under climate perturbed conditions with greater model development needed. bloom, flowering 
Many plant species, including pome fruit trees, annually cycle through biological events such as flowering and fruiting in response to climate cues. The timing of these responses is known as the phenology of the plant (Schwartz 2003). Historical trends in phenological events have been highlighted as useful indicators of system change in response to human induced climate change (Cleland et al. 2007; Menzel and Sparks 2006). To provide a global overview of these changes, Rosenzweig et al. (2008) collated over 28000 phenological studies across biological and physical spheres and found the majority of the significant observed changes were consistent with anthropogenic warming. Such studies have been conducted for historical pome fruit flowering phenology and generally report an advancement in phase timing (Chmielewski et al. 2004; Fujisawa and Kobayashi 2010; Grab and Craparo 2011; Kunz and Blanke 2011; Legave et al. 2012).

Adverse effects on production may eventuate if these observed advancement trends continue into the future. Impacts include increased spring frost risk, interruption to pollination processes and flow on effects to fruit maturity (Chmielewski et al. 2004; Grab and Craparo 2011; Guedon and Legave 2008; Lopez and Dejong 2007; Miller-Rushing et al. 2007; Zavalloni et al. 2006a). Given these potential consequences and expected future climate warming (IPCC, 2007) it is important to quantitatively estimate these impacts to inform appropriate management action. To date, only a few studies have projected climate change impacts on pome fruit flowering (Atkins and Morgan 1990; Blümel and Chmielewski 2012; Eccel et al. 2009).

To produce projected impacts, climate-phenology relationships defined by historical analyses must be used. Different methods have been applied to determine these relationships, including modelling to springtime temperatures (Chmielewski et al. 2004; Fujisawa and Kobayashi 2010; Grab and Craparo 2011; Miller-Rushing et al. 2007; Wolfe et al. 2005), incorporation of winter chill and spring growth effects (Atkins and Morgan 1990; Cannell and Smith 1986; Legave et al. 2008) and correlation to rainfall (Grab and Craparo 2011). This difference in method selection between studies is reflective of largely unknown physiological dependences on climate.

Given the various methods available and assumptions that need to be made within these methods it can be appreciated why few studies have investigated projected flowering phenology conditions. This study aims to highlight difficulties in constructing such projections due to methodological selection and restrictions within methods. To demonstrate some of these issues, flowering phenology was projected using results of a historical assessment for Australia (Darbyshire et al. 2013a). They applied two methods to investigate the dependence of full bloom on temperature; a 
fixed thermal time model and a sequential chill-growth model. The fixed thermal time model involved relating spring, or segments of spring temperatures, to observed phenophase timing. The sequential chill-growth method modelled the sequential and independent effects of winter chilling and sprng growth to determine flowering timing.

Variants of both these methods have been previously used in phenology projection studies. For instance, Zavalloni et al. (2006b) used a non-linear fixed thermal time approach to project changes to flowering phenology for sour cherry in Michigan. Their study found a general tendency towards flowering advancement with an average advancement of 12 days of the tight cluster stage by 2100 .

The sequential chill-growth model has also received application in projection analyses, with differing impacts reported (Atkins and Morgan 1990; Eccel et al. 2009). The mixed results reported are likely due to the inclusion of a winter chill component. Including winter chill creates less obvious outcomes from projection analyses as both winter and spring temperature conditions contribute to the determination of flowering timing.

Three broad outcomes may be expected when applying projected climate data to sequential chillgrowth models. Firstly, warmer winters may delay when chill accumulation begins and extend the time required to meet chilling requirements. If the time required to meet chilling requirements is protracted substantially, the start of the growth model will be postponed and may override any advancement in flowering due to warmer spring conditions. Atkins and Morgan (1990) described such a delay for pome fruit flowering in New Zealand, predicting later full bloom for pome fruit species under climate warming scenarios. This delay was attributed to a reduced rate of chill accumulation.

Conversely, in cold climates winter warming may have minimal effect on the time needed to reach threshold chill requirements. In this scenario, warmer spring temperatures would likely advance flowering. Legave et al. (2008) results agree with this, observing an advancement of early bloom of apple in France, although the rate of advancement was partly constrained by some lengthening of the chill period. Thirdly and finally, no change to flowering phenology is also possible. In this scenario, a lengthening of the time to reach chilling requirements would be balanced by an equivalent contraction in the time needed to fulfil growth requirements to reach the flowering phenophase.

This study had two primary aims. Firstly, projections of full bloom day-of-year were constructed according to two alternative phenology methods (fixed thermal time and sequential chill-growth modelling) using previously defined relationships for Australian pome fruit (Darbyshire et al. 2013a). 
Comparison of the results from each phenological model allowed assessment of the repercussions of method selection when projecting pome fruit flowering phenology.

Secondly, additional scrutiny of the sequential chill-growth model under future climate conditions was conducted via the use of four phenology simulations at five climatically diverse locations. This allowed greater investigation into the consequences of using sequential chill-growth models in projection analyses through considering a wider range of climates and a larger range of species physiological requirements than those in the first analysis.

\section{Material and Methods}

The two sites used to compare the two phenology models as well as the sites used in simulations of the sequential chill-growth model are shown in Figure 1. Background climate information for the study sites in both analyses is contained in Table 1.

\subsection{Phenology model comparison}

Comparison of two phenology methods (fixed thermal time and sequential chill-growth) under perturbed climate conditions was conducted. When applying such phenology models it is important to be aware of the predictive abilities of the models and the empirical nature of their construction. These models, which are frequently used, are proxies for poorly understood physiological processes (Campoy et al. 2011). Both the models applied in this study are constrained by several assumptions of physiological responses to temperature.

For the fixed thermal time method these include:

- Plant responses are restricted to the defined time interval (e.g. spring months) and these do not vary year-to-year;

- only heat drives phenophase development and;

- generally, higher temperatures accelerate biophysical processes and therefore phenophase timing.

Assumptions within the sequential chill-growth model include:

- Winter chilling is responsible for the release of buds from dormancy;

- the chill model is initiated on the same calendar day each year;

- dormancy is broken after accumulation of a quantifiable amount of chill which does not vary year-to-year;

- subsequent to breaking dormancy, bud development is driven by heat; 
- flowering is determined by the accumulation of a quantifiable amount of heat which does not vary year-to-year;

- there is no interaction between the accumulation of chill or heat and;

- the chill and growth models accurately represent the physiological processes.

Observed full bloom data used in the determination of the phenology models (Darbyshire et al. 2013a) were also included in the results to assist with interpretation. These observed data range in length from 24-28 years and were collected by the growers at Tatura and Yarra Valley. Darbyshire et al. (2013a) applied both the fixed thermal time and sequential chill-growth models to these historical observations. The observations determined parameters for the seven datasets according to both methods through statistical optimisation. These statistically determined parameters were used in here for climate projection analysis. Additional descriptions are contained in Darbyshire et al. (2013a).

\subsubsection{Fixed thermal time model}

The fixed thermal time model predicts full bloom day-of-year using a linear relationship to a springtime temperature variable. The model has the general form described in Equ 1.

$$
F B_{d a y}=b \times T_{t, p}+c
$$

where $F B_{\text {day }}$ is the predicted full bloom day-of-year, $b$ is the springtime coefficient (days $/{ }^{\circ} \mathrm{C}$ ), $T_{t, p}$ is the temperature variable, with $t$ representing the temperature factor (e.g. mean maximum temperature) and $p$ the time period (e.g. September), and $c$ is a constant.

Parameters of the model were determined for several varieties of apple and pear by Darbyshire et al. (2013a) using historical observations (Table 2). The models determined for each variety had different coefficients $(b)$, constants $(c)$ and springtime temperature variables $\left(T_{t, p}\right)$. These differences represent the differing physiological dependencies of the varieties to temperature to reach full bloom according to the fixed thermal time approach. All determined models were statistically significant ( $p$-value<0.05) and recorded r-squared values between 0.61-0.74 (Darbyshire et al. 2013a).

\subsubsection{Sequential chill-growth model}

The sequential chill-growth model predicts full bloom day-of-year using chill and growth sub-models. The model has the general form described in Equ 2.

$$
F B_{d a y}=\text { Chill }_{D O Y}+\text { Heat }_{d a y}
$$


where $F B_{d a y}$ is the predicted full bloom day-of-year, Chill ${ }_{D o r}$ is the day-of-year that chill is satisfied and $H_{e a t} t_{d a y}$ is the number of days needed, from Chill ${ }_{D O r}$, to satisfy growth requirements.

To fit the sequential chill-growth model, two different chill and growth sub-models were tested against the historical full bloom datasets (Darbyshire et al. 2013a). The two chill models were the Dynamic model (Erez et al. 1990; Fishman et al. 1987) and the Modified Utah model (Linvill 1990). The two growth models tested were the growing degree day (GDD) and growing degree hour (GDH) model (Anderson et al. 1986).

To implement the sequential chill-growth model several parameters must be defined within both the chill and growth sub-models. For the chill sub-model, a start day for the model to begin must be defined and a chill threshold must be allocated, which relates the physiological requirement of the species to break dormancy. For the sub-growth model, a base temperature above which growth is effective needs to be defined. This represents the minimum temperature that promotes growth for the species. Secondly, a growth threshold is needed which represents the accumulated exposure to growth promoting temperatures needed to reach the full bloom stage. Thus, four parameters across both chill and growth sub-models need to be defined to implement the sequential chill-growth model.

As with the fixed thermal time model, parameters for the sequential chill-growth model were previously determined by Darbyshire et al. (2013a) using historical observations (Table 3). The models determined were all statistically significant ( $p$-value $<0.05)$, recorded $r$-squared values between $0.75-0.85$ and root mean square error between 2.5-4.2 days (Darbyshire et al. 2013a).

\subsection{Sequential chill-growth simulations}

Two different chill thresholds and two different growth thresholds were tested within a sequential chill-growth model structure (four simulations in total) and applied to five climatically diverse sites (Figure 1). The simulations all used the Dynamic model for the chill sub-model and the GDH model for the growth sub-model. These two models were used as they were found the best performing models in historical analyses (Darbyshire et al. 2013a).

Two different chill thresholds were used to approximate different chill requirements of species; a high chill threshold of 70 chill portions and a low chill threshold of 30 chill portions (Table 4). This was performed as chill requirements to break dormancy are known to vary between species. 
Assessment of numerous pome fruit species chill requirements by Ghariani and Stebbins (1994) illustrates this variation in chill requirements.

Two different growth thresholds were used to simulate growth requirements; a high growth requirement of $7000 \mathrm{GDH}$ and a low growth requirement of $4000 \mathrm{GDH}$ (Table 4). Valentini et al. (2001) demonstrated different growth requirements for 15 apple cultivars finding the species with the lowest requirement was $70 \%$ of the cultivar with the highest requirement.

Other parameters in the sequential chill-growth model were fixed for consistency purposes. Within the chill component, the start date was set to 15 March and the base temperature within the growth model was fixed to $6^{\circ} \mathrm{C}$. The four simulations created represent cultivars with a high chill and high heat requirement $(\mathrm{HH})$, high chill and low heat requirement $(\mathrm{HL})$, low chill and high heat requirement (LH) or a low chill and low heat requirement (LL) (Table 4).

\subsection{Climate data}

Both historical and projected temperature data were used to perform the projection analyses. As discussed by Darbyshire et al. (2011), quality historical in situ data are not available at the sites in this study. Therefore, following Darbyshire et al. (2011) and Darbyshire et al. (2013a), historical daily minimum and maximum data from $1911-2009$ were sourced from $0.05^{\circ}$ by $0.05^{\circ}$ interpolated gridded temperature surfaces (Jones et al. 2009).

Climate projection data from six Atmosphere Ocean General Circulation Models (AOGCMs) were provided by the Queensland Climate Change Centre of Excellence (QCCCE). Darbyshire et al. (2013b) provide rational for the inclusion of these six AOGCMs (ECHO-G, MIROC3.2_medres, FGOALS-g1.0, BCCR-BCM2.0, MRI-CGCM2.3.2, CSIRO Mk3.5) following methods outlined by Whetton et al. (2012). The projection data were supplied as localised monthly minimum and maximum temperature perturbations per $1^{\circ} \mathrm{C}$ increase to mean global temperature from the 1975-2004 baseline. At each site, the projection data differ by month and temperature variable (maximum or minimum temperature) as interpreted by the AOGCMs. However, projections at all sites are relative to a $1^{\circ} \mathrm{C}$ increase in mean global temperatures. For instance, output from the CSIRO Mk3.5 model predicted maximum (minimum) January temperatures at Batlow would increase by $1.30^{\circ} \mathrm{C}\left(1.19^{\circ} \mathrm{C}\right)$ per $1^{\circ} \mathrm{C}$ increase to mean global temperatures. Perturbations at Huonville were less according to the CSIRO Mk3.5 model with maximum (minimum) January temperature perturbations of $0.93^{\circ} \mathrm{C}$ $\left(0.88^{\circ} \mathrm{C}\right)$ for a $1^{\circ} \mathrm{C}$ increase to mean global temperatures.

Using the approach described by Darbyshire et al. (2013b), the $1^{\circ} \mathrm{C}$ projected daily temperature datasets were created by the addition of localised minimum and maximum monthly temperature 
perturbations, according to each of the AOGCMs, to the historical dataset (1911-2009). Projections relative to 2 and $3^{\circ} \mathrm{C}$ increases to mean global temperatures were created by scaling up the perturbations through multiplication by 2 and 3 respectively. Similarly to the $1^{\circ} \mathrm{C}$ projections, these scaled perturbations were added to the historical daily dataset. This approach assumes historical variability continues into the future with further details are provided in Darbyshire et al. (2013b).

The Dynamic and Modified Utah chill models and the GDH growth model require hourly temperature data input. A sine-logarithmic interpolation algorithm was applied to the historical and projected daily minimum and maximum datasets to estimate hourly conditions (Darbyshire et al. 2011).

\subsection{Climate projections}

\subsubsection{Fixed thermal time model}

221 The climate datasets and the parameters in Table 2 were used to simulate historical and projected (for 1,2 and $3^{\circ} \mathrm{C}$ increases to mean global temperatures) full bloom day-of-year according to the fixed thermal time model. As 99 future representations were constructed for each AOGCM and for each level of warming, the $10^{\text {th }}$ and $90^{\text {th }}$ percentiles of these 99 data points were recorded as estimates of the future range of full bloom day-of-year. The collective projected range per degree increase in global average temperatures was then presented as the minimum $10^{\text {th }}$ percentile and the maximum $90^{\text {th }}$ percentile of the six AOGCMs.

\subsubsection{Sequential chill-growth model}

The climate datasets and the parameters outlined in Table 3 were used to simulate historical and projected full bloom day-of-year according to the sequential chill-growth model. Again, for each level of climate warming the estimated future full bloom range was represented as minimum $10^{\text {th }}$ percentile and the maximum $90^{\text {th }}$ percentile of the 99 projected data points according to the six AOGCMs. Under some projection scenarios chill thresholds were unable to be met. As such, if $20 \%$ or more of the dataset (total of 99 data points) did not meet the chill requirement the AOGCM was classified as 'NA'. If one or more AOGCM was classified as NA, the projection results were not reported as appropriate AOGCM variability could not be resolved.

As the sequential chill-growth method involves two sequential but independent steps, the projected length of both the chill and growth periods were reported to investigate the contribution of each component to the predicted full bloom day-of-year. 
The results of the four simulations of sequential chill-growth model, the second aim of this study, were constructed as described above with the model runs constrained by the parameters in Table 4 . These four simulations were applied to five study sites (Figure 1) for historical and projected 1, 2 and $3^{\circ} \mathrm{C}$ increases to mean global temperatures.

\section{Results}

\subsection{Phenology model comparison}

246 Projected changes to full bloom day-of-year (DOY) according to both the fixed thermal time and the sequential chill-growth methods are contained in Table 5. Observed full bloom DOY and historical estimation of full bloom according to historical meteorological data were additionally tabulated to assist with comparison. Further, the length of the chill and growth periods according to the sequential chill-growth model were also recorded.

Across the seven phenology data sets analysed the fixed thermal time model predicted a progressive advancement of full bloom with climate warming (Table 5; Springtime DOY). However, the same advancement was not evident in the results from the sequential chill-growth model which predicted minimal change to full bloom (Table 5; Sequential DOY). Figure 2 further illustrates these differences for Granny Smith apple. For this apple variety at Tatura, observed full bloom occurred between 271291 DOY. For a $2^{\circ} \mathrm{C}$ increase to global temperatures, the fixed thermal time model predicted the full bloom period will be between 259-276 DOY. However, the sequential chill-growth model indicated similar or potentially later full bloom compared with historical observations (271-296 DOY).

None of the $3^{\circ} \mathrm{C}$ projection scenarios were resolved for the sequential chill-growth model (Table 5). For two species, Williams' Bon Chretien pear (Tatura) and Granny Smith apple (Yarra Valley), the $2^{\circ} \mathrm{C}$ projections were also unable to be produced. This was a result of chilling requirements not being met under these scenarios.

By separating the chill and growth periods within the sequential chill-growth model it can be seen that these two effects tend to compensate each other under climate warming (Table 5 and Figure 3 ). A progressive lengthening of the chill period with increasing global temperatures is somewhat balanced by a contraction of the growth period, resulting in limited change to predicted full bloom. Figure 3 does show that with $2^{\circ} \mathrm{C}$ warming, lengthening of the chill period is not always fully compensated by a contraction in the growth period, resulting in a possible delay to full bloom. 


\subsection{Sequential chill-growth model simulations}

272 Predicted full bloom day-of-year according to the four simulations of the sequential chill-growth model were tabulated (Table 6). Progressive lengthening of the chill period and shortening of the growth period was predicted across all simulations and sites. The impact of this observation did differ between sites. For instance, the LL simulation at Huonville, a relatively cool site, did not record an observable shift in full bloom although a gradual lengthening of the chill period and contraction of the growth period was recorded. Conversely, the same simulation at Manjimup, a relatively warm site, indicated that the lengthening of the chill period was influential with full bloom likely delayed with climate warming.

Predicted changes to flowering timing were also observed to differ by simulation within a single site. For instance, with $3^{\circ} \mathrm{C}$ warming at Batlow under a LL simulation flowering may be slightly delayed, minimal change is expected with either a $\mathrm{LH}$ or $\mathrm{HL}$ simulation while the $\mathrm{HH}$ simulation indicated a slight advancement may be possible (Figure 4), although all these shifts were minor.

Different responses between the simulations were also evident at warmer sites as demonstrated by results at Manjimup (Figure 5). The LL simulation indicated a delay in flowering is likely while the LH simulation predicted similar timing to historical conditions, although with $3^{\circ} \mathrm{C}$ warming the range also extended towards a delay.

Three sites (Lenswood, Manjimup and Stanthorpe) reported unevaluated simulations for some of the projected warming scenarios. This was due to insufficient accumulation of chill to reach chilling requirements with climate warming.

\section{Discussion}

This analysis has demonstrated that phenological model selection will influence climate impact assessments, with projections of full bloom day-of-year differing between the fixed thermal time and sequential chill-growth methods (Table 5). Projections using the fixed thermal time model recorded progressive full bloom advancement with increasing global temperatures. Conversely, the sequential chill-growth model produced results with little change or a delay to full bloom with warming (Table 4). Management decisions based on results using one of these approaches would significantly differ. If producers were presented with results from the fixed thermal time modelling, adaptation responses such as investing in frost abatement infrastructure may be deployed. However, such a reaction would be unlikely if the results from the sequential chill-growth model were presented as limited change was predicted. 


\subsection{Fixed thermal time model}

303

This analysis indicated that the fixed thermal time model predicts continuously earlier full bloom as climate warming progresses. This result is related to the assumption that a fixed period of time is responsible for driving phenophase development. Such an outcome seems unrealistic especially when the potentially delaying influence of a longer time to break dormancy is considered (e.g. for meadow vegetation; Yu et al. (2010)). Further, the fixed time period assigned to driving phenological development is unlikely to remain stable with the advent of climate change. Specifically, it is likely that time periods different to historical conditions will be important for phenological development under future climates and use of historical relationships will not adequately represent those changes.

Recently, many of the assumptions of the fixed thermal time model in relation to predicting phenology under climate change have been challenged (Blümel and Chmielewski 2012). The authors reported that the fixed thermal time model tended to predict 'too early' bud burst, as was also observed in this analysis. Given the observations from this analysis and those by Blümel and Chmielewski (2012), application of the fixed thermal time model for projection analyses is not recommended.

\subsection{Sequential chill-growth model}

The structure of the sequential chill-growth model is more physiologically oriented than the fixed thermal time model as it incorporates both winter and spring responses, an aspect notably missing in the fixed thermal time model. To further investigate the sequential chill-growth model, four physiological simulations were applied to five climatically diverse sites to investigate the model with a wider range of chill and growth parameters and more diverse climates. This is important as the sequential chill-growth model has received wide application in historical flowering studies (Atkins and Morgan, 1990; Caffarra and Eccel, 2011; Cesaraccio et al. 2004; De Melo-Abreu et al. 2004; Farajzadeh et al. 2010; Legave et al. 2008; Mankotia et al. 2004; Rea and Eccel, 2006).

Depending on the study site and simulation, the model predicted full bloom to advance (e.g. Batlow; $\mathrm{HH}$ ), remain steady (e.g. Huonville; LL) or be delayed (e.g. Manjimup; LL). The results (Table 6) further indicated that with climate warming modelled changes to full bloom may differ not only between sites but also between varieties within a site. For instance, at Lenswood with $2^{\circ} \mathrm{C}$ warming, a LH parameterisation indicated a potential advancement in full bloom while, a $\mathrm{HL}$ parameterisation demonstrated little change. Some consistency across the simulations and sites was present with all predicted results trending towards an extension of the chill period and a contraction of the growth 
period. This is in agreement with recent results of historical Golden Delicious apple data investigated across Western Europe (Legave et al. 2012).

Different outcomes for different parameter choices within the sub-models highlight the need to adequately represent plant physiology. In the historical analysis of Australian pome fruit phenology (Darbyshire et al., 2013a), differently parameterised models often performed statistically similarly. For instance, the model for Josephine pear (Tatura), with $60 \mathrm{CP}$ and $7500 \mathrm{GDH}$ parameters, performed similarly to a model with $50 \mathrm{CP}$ and $4000 \mathrm{GDH}$ parameters. The simulations indicate that projections using such different parameter assumptions could lead to different predications. Correct parameterisation, based on physiology rather than statistical optimisation, is therefore necessary to create robust projections.

These results do clearly show a deficiency in the sequential chill-growth model when applied to projected climate conditions. Many of the model runs were unable to be evaluated ('NA' in Table 5 and Table 6) due to an inability to meet chilling requirements. For some sites this should not be cause for alarm. For instance, Manjimup is a mild location and does not currently cultivate high chill species so an inability to reach high chill requirements under future scenarios is of little consequence. However, for other locations such as Tatura and Yarra Valley where high chill species are grown this may become problematic and require management intervention such as the application of dormancy breaking chemicals (Petri et al. 2008; Sheard et al. 2009).

These unevaluated scenarios have two contrasting implications. Firstly, assuming the model structure adequately represents physiology, chilling requirements will no longer be met and impacts on production would be expected; delayed and protracted flowering, light and uneven ripening, and poor fruit development (Oukabli et al. 2003; Saure 1985; Voller 1986). Secondly, the sequential chillgrowth model is unable to capture the physiological response under climate change conditions.

This potential inability to represent physiology under future climates is likely due to the inherent rigidity of the sequential chill-growth model and the numerous assumptions needed to implement the model. The model stipulates that chill be fully satisfied prior to allowing any response to growth promoting temperatures. Under current climate circumstances this may be representative if chill requirements are satisfied in early to mid winter, prior to the onset of warmer temperatures. However, as chill accumulation becomes protracted interaction with warmer growth promoting temperatures is likely. The sequential chill-growth model has no mechanism to balance the countering influences of the accumulation of winter chill and spring growth responses. 
Another limitation to the implementation of the sequential chill-growth model is the need to define parameters within the model. In the analysis of the historical data (Darbyshire et al. 2013a) many possible values for the initiation of the chill period, the chill threshold, the base temperature and the growth threshold were tested. This was necessary as field experimentation to determine these values has not been conducted. As such, the parameters used in this analysis were selected based on statistical performance in these historical assessments, not physiologically tested responses. Thus, actual parameters may differ from those used here and different projected results may be obtained. Further, some of the parameters are unlikely to remain stable in a changing climate. For instance, a fixed date to initiate the chill model is likely unrealistic, especially with future climate warming.

A recent study provides a methodology that removes the need to test various options for many of the parameters in the sequential chill-growth model. Luedeling and Gassner (2012) proposed using a statistical method, Partial Least Squares (PLS) regression to evaluate spring phenology records for walnuts. This method was shown to be useful in identifying time periods that relate to effective chill and growth phases and assisted to remove the need to make several parameter assumptions, like those made by Darbyshire et al. (2013a).

PLS regression is a novel approach to investigate chill and growth parameters and wider application is needed to further illustrate the robustness of the method. An important caveat to using PLS regression is the requirement to use historical phenological records, with at least 15 years recommended (Luedeling et al. 2012). PLS is still a statistical method to represent plant physiology and although may be an improvement to methods used in the historical analysis of this data, physiological understanding is still needed. As demonstrated by the low representation of agricultural phenological records in the Southern Hemisphere (Rosenzweig et al. 2008), field monitoring and recording of phenological events remains critically important for future research needs.

\subsection{Further research}

This analysis has shown that use of the fixed thermal time model for climate projection analysis is likely to produce unrealistic results, further supporting the Blümel and Chmielewski (2012) critique of this method. The sequential chill-growth method was more convincing than the fixed thermal time model. Further investigation into this model structure is needed, especially in regard to climate change impact research. Investigation is needed to determine if different chill and growth sub-model choices will further influence projections using the sequential chill-growth phenology modelling structure. For instance, direct comparisons between the Dynamic and Modified Utah chill models and the GDD and GDH growth models. Greater investigation into the sequential model under climate 
change conditions considering the chill model start date and the base temperature in the growth model, which were fixed in the simulations here, will also assist in better understanding of the applicability of the sequential chill-growth model under climate perturbed conditions.

Even in lieu of further investigations into the sequential chill-growth model, this study has shown that the model structure has constraints when used to project future phenology conditions. Other models of flowering phenology have been proposed and may assist in creating meaningful climate projections of spring flowering phenology. For instance, Cannell and Smith (1983) proposed thermal time-chilling curves where chill and heat accumulation can moderate each other. The method assumes that for high chill seasons less heat will be required to reach bud burst and conversely for low chill years more heat will be needed. Minimum chill and growth thresholds are still incorporated and if either is not met it is assumed bud burst will not occur. Some rigidity still exists, with Cannell and Smith (1983) and Harrington et al. (2010) both defining time periods when the chilling and growth functions are effective, however these two windows can overlap.

A combination of several existing methods may be an improvement on current approaches. The early work by Cannell and Smith (1983) using thermal-chill curves contains an appealing structure due to more flexible chill and growth threshold requirements and interaction between these values. Building on the thermal-chill curve approach including aspects of the Dynamic chilling model may also prove beneficial. This chill model was derived from a physiological perspective and is gaining support for its physiological structure (Campoy et al. 2011; Luedeling 2012; Luedeling and Brown 2010; Luedeling et al. 2011). Development of a growth model with a similar structure to the Dynamic model would be an appropriate option to allow integration of the two effects. Ideally, a whole-oftree model needs to be developed to assess future impacts on pome fruit trees incorporating multiyear and interacting physiological effects.

\section{Conclusions}

Given phenology models are proxies for unknown physiological processes, projection results including those in this study rely on these models being good representations of tree physiology. This assumption needs greater testing as do the structures of the models to advance climate impact analyses of fruit flowering phenology.

It is apparent from the results of this study that phenological method selection will influence projected pome fruit flowering predictions. As such, impacts and adaptation strategies may differ dependent on the approach employed and could lead to mismanagement or maladaptation. Notable 
differences in results from alternative methods are likely to manifest in locations, such as Australia, where incremental warming will begin to affect the likelihood of meeting chilling requirements. The fixed thermal time method was found to produce unrealistic results due to the simplistic assumptions in this model. The sequential chill-growth model may better capture the process, however it still contains structural rigidity and the stability of parameter selections under future climates is questionable.

Thus, greater research into the adequacy of phenology models in representing tree physiology is needed. To address the likely impacts of climate change on pome fruit flowering phenology, and other species with chill and growth response mechanisms, better understanding and modelling of the underlying physiological process is required. To fulfil this need, more detailed field and laboratory work aimed at extending current modelling options is required.

\section{Acknowledgements}

We thank the Australian Bureau of Meteorology for providing the historical meteorological data and QCCCE and CSIRO for the climate projection data used in the analysis. We further thank Chris Turnbull and Kevin Sanders for granting access to their orchard records and experience. Finally, Kevin Hennessy (CSIRO), Ian Smith (Bureau of Meteorology) and Jim Ricketts (QCCCE) provided valuable advice on projection methodologies.

\section{References}

Anderson JL, Richardson EA, Kesner CD (1986) Validation of chill unit and flower bud phenology models for 'Montmorency' sour cherry. Acta Hortic 184:71-78.

Atkins TA, Morgan ER (1990) Modelling the effection of possible climate change scenarios on the phenology of New-Zealand crops. Acta Hortic 276:201-208.

Blümel K, Chmielewski FM (2012) Shortcomings of classical phenological forcing models and a way to overcome them. Agric For Meteorol 164:10-19.

Caffarra A, Eccel E (2011) Projecting the impacts of climate change on the phenology of grapevine in a mountain area. Aust J Grape Wine R 17:52-61.

Campoy JA, Ruiz D, Egea , (2011) Dormancy in temperate fruit trees in a global warming context: A review. Sci Hortic 130:357-372.

Cannell M, Smith R (1986) Climate warming, spring budburst and forest damage on trees. J Appl Ecol 23:177-191.

Cannell MGR, Smith RI (1983) Thermal time, chill days and prediciton of budburst in picea-sitchensis. J Appl Ecol 20:951-963. 
Cesaraccio C, Spano D, Snyder RL, Duce P (2004) Chilling and forcing model to predict bud-burst of crop and forest species. Agric For Meteorol 126:1-13.

Chmielewski FM, Muller A, Bruns E (2004) Climate changes and trends in phenology of fruit trees and field crops in Germany, 1961-2000. Agric For Meteorol 121:69-78.

Cleland EE, Chuine I, Menzel A, Mooney HA, Schwartz MD (2007) Shifting plant phenology in response to global change. Trends Ecol Evol 22:357-365.

Darbyshire R, Webb L, Goodwin I, Barlow S (2011) Winter chilling trends for deciduous fruit trees in Australia. Agric For Meteorol 151:1074-1085.

Darbyshire R, Webb L, Goodwin I, Barlow EWR (2013a) Evaluation of recent trends in Australian pome fruit spring phenology. Int J Biometeorol 57:409-421.

Darbyshire R, Webb L, Goodwin I, Barlow EWR (2013b). Impact of future warming on winter chilling in Australia. Int J Biometeorol 57:355-366.

De Melo-Abreu JP, Barranco D et al (2004) Modelling olive flowering date using chilling for dormancy release and thermal time. Agric For Meteorol 125:117-127.

Eccel E, Rea R, Caffarra A, Crisci A, (2009) Risk of spring frost to apple production under future climate scenarios: the role of phenological acclimation. Int J Biometeorol 53:273-286.

Erez A, Fishman S, Linsley-Noakes GC, Allan P (1990) The dynamic model for rest completion in peach buds. Acta Hortic 279:165-174.

Farajzadeh M, Rahimi M, Kamali GA, Mavrommatis T (2010) Modelling apple tree bud burst time and frost risk in Iran. Meteorol Appl 17:45-52.

Fishman S, Erez A, Couvillon GA (1987) The temperature-dependence of dormancy breaking in plants - Computer-simulation of processes studied under controlled temperatures. J Theor Biol 126:309-321.

Fujisawa M, Kobayashi K (2010) Apple (Malus pumila var. domestica) phenology is advancing due to rising air temperature in northern Japan. Global Change Biol 16:2651-2660.

Ghariani K, Stebbins RL (1994) Chilling requirements of apple and pear cultivars. Fruit Varieties J 48:215-222.

Grab S, Craparo A (2011) Advance of apple and pear tree full bloom dates in response to climate change in the southwestern Cape, South Africa: 1973-2009. Agric For Meteorol 151:406-413.

Guedon Y, Legave J (2008) Analyzing the time-course variation of apple and pear tree dates of flowering stages in the global warming context. Ecol Modell 219:189-199.

Harrington CA, Gould PJ, St.Clair JB (2010) Modeling the effects of winter environment on dormancy release of Douglas-fir. Forest Ecol Manag 259:798-808.

IPCC (2007) Climate Change 2007: The Physical Science Basis-Contribution of Working Group I to the Fourth Assessment Report of the Intergovernmental Panel on Climate Change, Cambridge University, Cambridge.

Jones D, Wang W, Fawcett R (2009). High-quality spatial climate data-sets for Australia. Aust Meteorol Oceanogr J 58:233-248.

Kunz A, Blanke MM (2011) Effects of global climate change on apple 'Golden Delicious' phenology Based on 50 years of meteorological and phenological data in klein-altendorf. Acta Hortic 903:1121-1126. 
Legave J, Farrera I, Almeras T, Calleja M (2008) Selecting models of apple flowering time and understanding how global warming has had an impact on this trait. J Hortic Sci Biotech 83:76-84.

Legave JM, Blanke M, Christen D, Giovannini D, Mathieu V, Oger R (2012) A comprehensive overview of the spatial and temporal variability of apple bud dormancy release and blooming phenology in Western Europe. Int J Biometeorol. doi:10.1007/s00484-012-0551-9.

Linvill DE (1990) Calculating chilling hours and chill units from daily maximum and minimum temperature observations. HortScience 25:14-16.

Lopez G, Dejong TM (2007). Spring temperatures have a major effect on early stages of peach fruit growth. J Hortic Sci Biotech 82:507-512.

Luedeling E, Brown P (2010) A global analysis of the comparability of winter chill models for fruit and nut trees. Int J Biometeorol 55:411-421.

Luedeling E Girvetz EH, Semenov MA, Brown PH (2011) Climate change affects winter chill for temperate fruit and nut trees. Plos One 6:e20155.

Luedeling E (2012) Climate change impacts on winter chill for temperate fruit and nut production: A review. Sci Hortic 144:218-229.

Luedeling E,Gassner A (2012) Partial least squares regression for analyzing walnut phenology in California. Agric For Meteorol 158-159:43-52.

Luedeling E, Kunz A, Blanke MM (2012) Identification of chilling and heat requirements of cherry trees- a statistical approach. Int J Biometeorol 1-11 (in press).

Mankotia MS, Chauhan PS, Sud A, Jindal KK (2004) Estimation of effective chilling hours and GDH degrees $\mathrm{C}$ requirement and its significance in predicting full bloom in delicious apple. Acta Hortic 662:83-86.

Menzel A, Sparks T (2006) Temperature and plant development: phenology and seasonality. In: Morison JIL, Morecroft MD (ed) Plant growth and climate change, Blackwell Publishing, Kundli, pp 238.

Miller-Rushing AJ, Katsuki T, Primack RB, Ishii Y, Sang DL, Higuchi H (2007) Impact of global warming on a group of related species and their hybrids: Cherry tree (Rosaceae) flowering at Mt. Takao, Japan. Am J Bot 94:1470-1478.

Oukabli A, Bartolin S, Viti R (2003) Anatomical and morphological study of apple (Malus X domestica Borkh.) flower buds growing under inadequate winter chilling. J Hortic Sci Biotech 78:580585.

Petri JL, Leite GB, Putti GL (2008) Apple tree budbreak promoters in mild winter conditions. Acta Hortic 774:291-296.

Rea R, Eccel E (2006) Phenological models for blooming of apple in a mountainous region. Int J Biometeorol 51:1-16.

Rosenzweig C, Karoly D et al (2008) Attributing physical and biological impacts to anthropogenic climate change. Nature 453:353-358.

Saure MC (1985) Dormancy release in deciduous fruit trees. Hortic Rev 7:239-300.

Schwartz M (2003) Phenology: An integrative environmental science. Kluwer Academic Publishers, Netherlands. 
Sheard AG, Johnson SD,Cook NC (2009) Effect of timing and concentration of rest breaking agents on budburst in 'Bing' sweet cherry under conditions of inadequate winter chilling in South Africa. S Afr J Plant Soil 26:73-79.

Valentini N, Me G, Ferrero R,Spanna F (2001) Use of bioclimatic indexes to characterize phenological phases of apple varieties in Northern Italy. Int J Biometeorol 45:191-195.

Voller CFP (1986) Predicting rest-breaking: Principles and problems. Decid Fruit Grow 36:302-308.

Whetton P, Hennessy K, Clarke J, McInnes K, Kent D (2012) Use of representative climate futures in impact and adaptation assessment. Clim Change 115:433-442.

Wolfe DW, Schwartz MD, Lakso AN, Otsuki Y, Pool RM, Shaulis NJ (2005). Climate change and shifts in spring phenology of three horticultural woody perennials in northeastern USA. Int J Biometeorol 49:303-309.

Yu H, Luedeling E, Xu J, (2010) Winter and spring warming result in delayed spring phenology on the Tibetan Plateau. Proc Nat Acad Sci 107:22151-22156.

Zavalloni C, Andresen JA, Flore JA (2006a) Phenological models of flower bud stages and fruit growth of 'Montmorency' sour cherry based on growing degree-day accumulation. J Am Soc Hortic Sci 131:601-607.

Zavalloni C, Andersen JA et al (2006b) The Pileus project: Climatic impacts on sour cherry production in the Great Lakes region in past and projected future time frames. Acta Hortic 707:101-108. 
564 Figure 1 Sites used to compare phenology methods (asterisks) and for sequential chill-growth model simulations (points)

565 Figure 2 Observed and modelled historical and projected full bloom timing for Granny Smith apple (Tatura) using the fixed thermal time and the sequential chill-growth models (day-of-year, DOY).

567 Figure 3 Modelled historical and projected chill and growth period lengths and full bloom timing using the sequential chillgrowth model for Granny Smith apple (Tatura). The first panel is the chill period length (number of days from 15 May to reach the chill threshold), the second panel is the growth period length (number of days between chill satisfaction and heat threshold) and the final panel is predicted full bloom timing (day-of-year, DOY).

571 Figure 4 Full bloom simulations at Batlow according to low chill and low heat (LL), low chill and high heat (LH), high chill and low heat $(\mathrm{HL})$ and high chill and high heat $(\mathrm{HH})$. The chill period was measured in days from March 15 to reach the chill

573 threshold, the growth period was measured in days from chill satisfaction to when growth threshold was met, and full 574 bloom timing was measured in day-of-year (DOY).

575 Figure 5 Full bloom simulations at Manjimup according to low chill and low heat (LL) and low chill and high heat (LH). The 576 chill period was measured in days from March 15, the growth period was measured in days from chill satisfaction to when 577 growth threshold was met, and full bloom timing was measured in day-of-year (DOY). Note the high chill simulations were 578 unable to be projected. 
Table 1 Historical climate conditions at the study sites based on data 1911-2009.

\begin{tabular}{lrrr}
\hline Study site & Elevation $(\mathrm{m})$ & $\begin{array}{r}\text { Mean winter } \\
\text { temperature range }\left({ }^{\circ} \mathrm{C}\right)\end{array}$ & $\begin{array}{r}\text { Mean spring } \\
\text { temperature range }\left({ }^{\circ} \mathrm{C}\right)\end{array}$ \\
\hline Tatura* & 112 & $7.8-9.9$ & $12.9-17.1$ \\
Yarra Valley* & 182 & $7.4-9.2$ & $11.6-14.5$ \\
Batlow & 787 & $3.8-6.2$ & $8.1-15.0$ \\
Stanthorpe & 801 & $7.6-10.3$ & $13.2-17.0$ \\
Lenswood & 430 & $7.6-9.9$ & $11.5-15.1$ \\
Huonville & 7 & $6.7-8.8$ & $9.8-12.7$ \\
Manjimup & 287 & $9.6-12.4$ & $12.0-15.3$ \\
\hline
\end{tabular}

581

*sites used for phenology model comparison only

Table 2 Fixed thermal time model parameters determined by Darbyshire et al. (2013a). The two variables in the springtime parameters represent the mean temperature variable used (Tmean is mean daily temperature and Tmax is mean maximum daily temperature) and the time period the temperature variables are applied to (AugSep is August and September, Sep is September).

\begin{tabular}{llrrr}
\hline Location & Variety & $\begin{array}{r}\text { Springtime } \\
\text { parameters }(\boldsymbol{t}, \boldsymbol{p})\end{array}$ & $\begin{array}{r}\text { Springtime } \\
\text { coefficient }(\boldsymbol{b}) \\
\left.\text { (days } /{ }^{\circ} \mathbf{C}\right)\end{array}$ & $\begin{array}{r}\text { Springtime } \\
\text { constant }(\boldsymbol{c}) \\
\text { (days) }\end{array}$ \\
\hline \multirow{4}{*}{ Tatura } & Granny Smith apple & Tmean, AugSep & -6.5 & -0.4 \\
\cline { 2 - 5 } & Josephine pear & Tmax, AugSep & -4.3 & -0.3 \\
\cline { 2 - 5 } & Packham's Triumph pear & Tmean, AugSep & -6.4 & -0.0 \\
\cline { 2 - 5 } & Williams' Bon Chretien pear & Tmean, Sep & -6.1 & -0.6 \\
\hline \multirow{2}{*}{ Yarra } & Golden Delicious apple & Tmax, AugSep & -5.5 & -0.1 \\
\cline { 2 - 5 } Valley & Red Delicious apple & Tmean, AugSep & -7.5 & -0.0 \\
\cline { 2 - 5 } & Granny Smith apple & Tmean, AugSep & -7.7 & 0.1 \\
\hline
\end{tabular}

586

Table 3 Sequential chill-growth model parameters determined by Darbyshire et al. (2013a). Description of the chill parameters; the model used, the day-of-year the model starts (start date) and the threshold amount of chill required to break winter dormancy (Threshold). CP is chill portions and CU is chill units. Description of the growth parameters; the model used, the base temperature (Base T) and the threshold growth units required to reach full bloom (Threshold). GDH and growing degree hours, GDD are growing degree days.

\begin{tabular}{|c|c|c|c|c|c|c|c|}
\hline \multirow[b]{2}{*}{ Location } & \multirow[b]{2}{*}{ Variety } & \multicolumn{3}{|c|}{ Chill parameters } & \multicolumn{3}{|c|}{ Growth parameters } \\
\hline & & Chill model & Start date & Threshold & $\begin{array}{c}\text { Growth } \\
\text { model }\end{array}$ & Base T & Threshold \\
\hline \multirow{4}{*}{ Tatura } & $\begin{array}{l}\text { Granny } \\
\text { Smith apple }\end{array}$ & Dynamic & 15-May & $60 \mathrm{CP}$ & GDH & $4^{\circ} \mathrm{C}$ & $8500 \mathrm{GDH}$ \\
\hline & $\begin{array}{l}\text { Josephine } \\
\text { pear }\end{array}$ & Dynamic & 15-Apr & $60 \mathrm{CP}$ & GDH & $4^{\circ} \mathrm{C}$ & $7500 \mathrm{GDH}$ \\
\hline & $\begin{array}{l}\text { Packham's } \\
\text { Triumph } \\
\text { pear }\end{array}$ & Dynamic & 15-Apr & $60 \mathrm{CP}$ & GDH & $4^{\circ} \mathrm{C}$ & $7500 \mathrm{GDH}$ \\
\hline & $\begin{array}{l}\text { Williams' } \\
\text { Bon Chretien } \\
\text { pear }\end{array}$ & Dynamic & 15-Apr & $70 \mathrm{CP}$ & GDD & $7^{\circ} \mathrm{C}$ & 210 GDD \\
\hline $\begin{array}{l}\text { Yarra } \\
\text { Valley }\end{array}$ & $\begin{array}{l}\text { Golden } \\
\text { Delicious } \\
\text { apple }\end{array}$ & Dynamic & 1-Apr & $75 \mathrm{CP}$ & GDH & $8^{\circ} \mathrm{C}$ & $5000 \mathrm{GDH}$ \\
\hline
\end{tabular}




\begin{tabular}{lllllll}
\hline $\begin{array}{l}\text { Red } \\
\text { Delicious } \\
\text { apple }\end{array}$ & Dynamic & 15-Apr & $75 \mathrm{CP}$ & $\mathrm{GDH}$ & $5^{\circ} \mathrm{C}$ & $7500 \mathrm{GDH}$ \\
$\begin{array}{llllll}\text { Granny } \\
\text { Smith apple }\end{array}$ & Modified & 15-Mar & $1150 \mathrm{CU}$ & $\mathrm{GDH}$ & $4^{\circ} \mathrm{C}$ & $8500 \mathrm{GDH}$ \\
& Utah & & & & &
\end{tabular}

592

593

595

596

597

598

Table 4 Parameter definitions for the four simulations of the sequential chill-growth model. The dynamic chill model and growing degree hour growth model were used for all simulations. CP is chill portions and GDH are growing degree hours

\begin{tabular}{llcccc}
\hline & \multicolumn{2}{c}{ Chill parameters } & \multicolumn{2}{c}{ Growth parameters } \\
\hline Simulation & $\begin{array}{l}\text { Simulation } \\
\text { code }\end{array}$ & $\begin{array}{l}\text { Start date } \\
\text { (fixed) }\end{array}$ & Threshold & $\begin{array}{l}\text { Base T } \\
\text { (fixed) }\end{array}$ & Threshold \\
\hline $\begin{array}{l}\text { High chill/ High } \\
\text { heat }\end{array}$ & $\mathrm{HH}$ & 15 March & $70 \mathrm{CP}$ & $6^{\circ} \mathrm{C}$ & $7000 \mathrm{GDH}$ \\
\hline $\begin{array}{l}\text { High chill/ Low } \\
\text { heat }\end{array}$ & $\mathrm{HL}$ & 15 March & $70 \mathrm{CP}$ & $6^{\circ} \mathrm{C}$ & $4000 \mathrm{GDH}$ \\
\hline $\begin{array}{l}\text { Low chill/ High } \\
\text { heat }\end{array}$ & $\mathrm{LH}$ & 15 March & $30 \mathrm{CP}$ & $6^{\circ} \mathrm{C}$ & $7000 \mathrm{GDH}$ \\
\hline $\begin{array}{l}\text { Low chill/ Low } \\
\text { heat }\end{array}$ & $\mathrm{LL}$ & 15 March & $30 \mathrm{CP}$ & $6^{\circ} \mathrm{C}$ & $4000 \mathrm{GDH}$ \\
\hline
\end{tabular}

Table 5 Observed, modelled historical and projected full bloom timing (day-of-year, DOY) using the fixed thermal time and sequential chill-growth model. Chill length and growth length indicate the length in days of the chill and growth components applicable to the sequential chill-growth model only.

\begin{tabular}{|c|c|c|c|c|c|c|}
\hline \multirow[t]{10}{*}{ Location } & Variety & Projection & $\begin{array}{l}\text { Springtime } \\
\text { (DOY) }\end{array}$ & $\begin{array}{l}\text { Sequential } \\
\text { (DOY) }\end{array}$ & $\begin{array}{l}\text { Chill } \\
\text { length } \\
\text { (\# days) }\end{array}$ & $\begin{array}{l}\text { Growth } \\
\text { length } \\
\text { (\# days) }\end{array}$ \\
\hline & \multirow{5}{*}{$\begin{array}{l}\text { Granny } \\
\text { Smith apple }\end{array}$} & Observed & \multicolumn{2}{|c|}{$271-291$} & & \\
\hline & & Historical & $275-285$ & $273-286$ & $82-90$ & $52-65$ \\
\hline & & $+1^{\circ} \mathrm{C}$ & $267-280$ & $271-283$ & 85-103 & $41-58$ \\
\hline & & $+2^{\circ} \mathrm{C}$ & $259-276$ & $271-296$ & 89-131 & $30-53$ \\
\hline & & $+3^{\circ} \mathrm{C}$ & $251-272$ & NA & & NA \\
\hline & & Observed & 26 & -281 & & \\
\hline & & Historical & $267-276$ & $263-275$ & $98-112$ & $53-67$ \\
\hline & Josepnine & $+1^{\circ} \mathrm{C}$ & $260-273$ & $261-275$ & $102-127$ & $40-60$ \\
\hline & & $+2^{\circ} \mathrm{C}$ & $253-270$ & $261-284$ & $110-150$ & $29-52$ \\
\hline \multirow{11}{*}{ Tatura } & & $+3^{\circ} \mathrm{C}$ & $247-267$ & NA & & NA \\
\hline & \multirow{5}{*}{$\begin{array}{l}\text { Packham's } \\
\text { Triumph } \\
\text { pear }\end{array}$} & Observed & \multicolumn{2}{|c|}{$262-283$} & & \\
\hline & & Historical & $264-278$ & $263-275$ & $98-112$ & $53-67$ \\
\hline & & $+1^{\circ} \mathrm{C}$ & $254-274$ & $261-275$ & $102-127$ & $40-60$ \\
\hline & & $+2^{\circ} \mathrm{C}$ & $245-269$ & $261-284$ & $110-150$ & $29-52$ \\
\hline & & $+3^{\circ} \mathrm{C}$ & $235-264$ & NA & & NA \\
\hline & \multirow{5}{*}{$\begin{array}{l}\text { Williams' } \\
\text { Bon } \\
\text { Chretien } \\
\text { pear }\end{array}$} & Observed & \multicolumn{2}{|c|}{$268-289$} & & \\
\hline & & Historical & $270-283$ & $270-284$ & $111-127$ & $46-63$ \\
\hline & & $+1^{\circ} \mathrm{C}$ & $263-279$ & $267-286$ & $117-151$ & $30-55$ \\
\hline & & $+2^{\circ} \mathrm{C}$ & $255-275$ & NA & & NA \\
\hline & & $+3^{\circ} \mathrm{C}$ & $248-271$ & NA & & NA \\
\hline \multicolumn{2}{|l|}{ Yarra } & Observed & \multicolumn{2}{|c|}{$272-299$} & & \\
\hline
\end{tabular}




\begin{tabular}{|c|c|c|c|c|c|c|}
\hline \multirow{5}{*}{\multicolumn{2}{|c|}{$\begin{array}{ll}\text { Valley } & \text { Golden } \\
& \text { Delicious } \\
& \text { apple }\end{array}$}} & \multirow{2}{*}{\multicolumn{2}{|c|}{ Historical }} & \multirow{2}{*}{\multicolumn{2}{|c|}{$115-132$}} & \multirow[b]{2}{*}{$61-80$} \\
\hline & & & & & & \\
\hline & & $+1^{\circ} \mathrm{C}$ & $271-286$ & $275-293$ & $120-144$ & $47-72$ \\
\hline & & $+2^{\circ} \mathrm{C}$ & $263-282$ & $274-298$ & $126-173$ & $31-62$ \\
\hline & & $+3^{\circ} \mathrm{C}$ & $256-276$ & NA & \multicolumn{2}{|r|}{ NA } \\
\hline \multirow{10}{*}{ Valley } & \multirow{5}{*}{$\begin{array}{l}\text { Red } \\
\text { Delicious } \\
\text { apple }\end{array}$} & Observed & \multicolumn{2}{|c|}{$272-298$} & & \\
\hline & & Historical & $279-290$ & $280-295$ & $109-121$ & $58-77$ \\
\hline & & $+1^{\circ} \mathrm{C}$ & $271-286$ & $275-292$ & 113-133 & $45-66$ \\
\hline & & $+2^{\circ} \mathrm{C}$ & $262-281$ & $275-298$ & 117-160 & $32-58$ \\
\hline & & $+3^{\circ} \mathrm{C}$ & $254-277$ & NA & \multicolumn{2}{|r|}{ NA } \\
\hline & \multirow{5}{*}{$\begin{array}{l}\text { Granny } \\
\text { Smith apple }\end{array}$} & Observed & \multicolumn{2}{|c|}{$270-292$} & & \\
\hline & & Historical & $273-285$ & $270-287$ & $113-138$ & $70-91$ \\
\hline & & $+1^{\circ} \mathrm{C}$ & $265-280$ & $268-288$ & $122-163$ & $47-78$ \\
\hline & & $+2^{\circ} \mathrm{C}$ & $256-276$ & NA & & NA \\
\hline & & $+3^{\circ} \mathrm{C}$ & $278-271$ & NA & & NA \\
\hline
\end{tabular}

599 For reference, the ranges of DOY for each month are: August 213-243; September = 244-273; October = 274-304. Chill

600 and growth length (number of days) are in regard to the sequential chill-growth model only.

601

Table 6 Chill length, growth length and full bloom (day-of-year, DOY) for each of the four simulations for historical and $1^{\circ} \mathrm{C}$,

$2^{\circ} \mathrm{C}$ and $3^{\circ} \mathrm{C}$ increases to average global temperatures.

\begin{tabular}{|c|c|c|c|c|c|}
\hline Location & Simulation & Projection & $\begin{array}{r}\text { Chill length } \\
\text { (days) }\end{array}$ & $\begin{array}{r}\text { Growth length } \\
\text { (days) }\end{array}$ & $\begin{array}{r}\text { Full bloom } \\
\text { (DOY) }\end{array}$ \\
\hline \multirow{16}{*}{ Batlow } & \multirow{4}{*}{ LL } & Historical & $61-78$ & 65-106 & $203-250$ \\
\hline & & $1^{\circ} \mathrm{C}$ & $65-88$ & 70-106 & $216-260$ \\
\hline & & $2^{\circ} \mathrm{C}$ & 69-99 & 68-103 & $221-261$ \\
\hline & & $3^{\circ} \mathrm{C}$ & $74-108$ & 58-96 & $228-260$ \\
\hline & \multirow{4}{*}{ LH } & Historical & $61-78$ & 114-145 & $252-291$ \\
\hline & & $1^{\circ} \mathrm{C}$ & $65-88$ & $107-140$ & $256-291$ \\
\hline & & $2^{\circ} \mathrm{C}$ & 69-99 & $96-134$ & 258-291 \\
\hline & & $3^{\circ} \mathrm{C}$ & $74-108$ & $81-125$ & $254-286$ \\
\hline & \multirow{4}{*}{$\mathrm{HL}$} & Historical & 115-131 & $61-82$ & $256-280$ \\
\hline & & $1^{\circ} \mathrm{C}$ & $119-142$ & $53-78$ & $257-280$ \\
\hline & & $2^{\circ} \mathrm{C}$ & $123-152$ & $40-75$ & $257-281$ \\
\hline & & $3^{\circ} \mathrm{C}$ & $128-165$ & $28-66$ & $257-278$ \\
\hline & \multirow{4}{*}{$\mathrm{HH}$} & Historical & $115-131$ & $87-110$ & 284-309 \\
\hline & & $1^{\circ} \mathrm{C}$ & 119-142 & 74-103 & $283-307$ \\
\hline & & $2^{\circ} \mathrm{C}$ & $123-152$ & 59-96 & 279-304 \\
\hline & & $3^{\circ} \mathrm{C}$ & $128-165$ & $44-87$ & 275-301 \\
\hline \multirow{9}{*}{ Huonville } & \multirow{4}{*}{ LL } & Historical & 59-74 & 71-90 & 209-233 \\
\hline & & $1^{\circ} \mathrm{C}$ & $63-82$ & $65-85$ & $210-236$ \\
\hline & & $2^{\circ} \mathrm{C}$ & $68-92$ & $57-82$ & $208-238$ \\
\hline & & $3^{\circ} \mathrm{C}$ & $72-103$ & $48-76$ & $208-239$ \\
\hline & \multirow{4}{*}{ LH } & Historical & 59-74 & $115-134$ & $254-274$ \\
\hline & & $1^{\circ} \mathrm{C}$ & $63-82$ & $104-127$ & $250-272$ \\
\hline & & $2^{\circ} \mathrm{C}$ & 68-92 & 89-119 & $245-272$ \\
\hline & & $3^{\circ} \mathrm{C}$ & $72-103$ & 75-109 & 241-269 \\
\hline & $\mathrm{HL}$ & Historical & $113-129$ & $59-76$ & $254-269$ \\
\hline
\end{tabular}




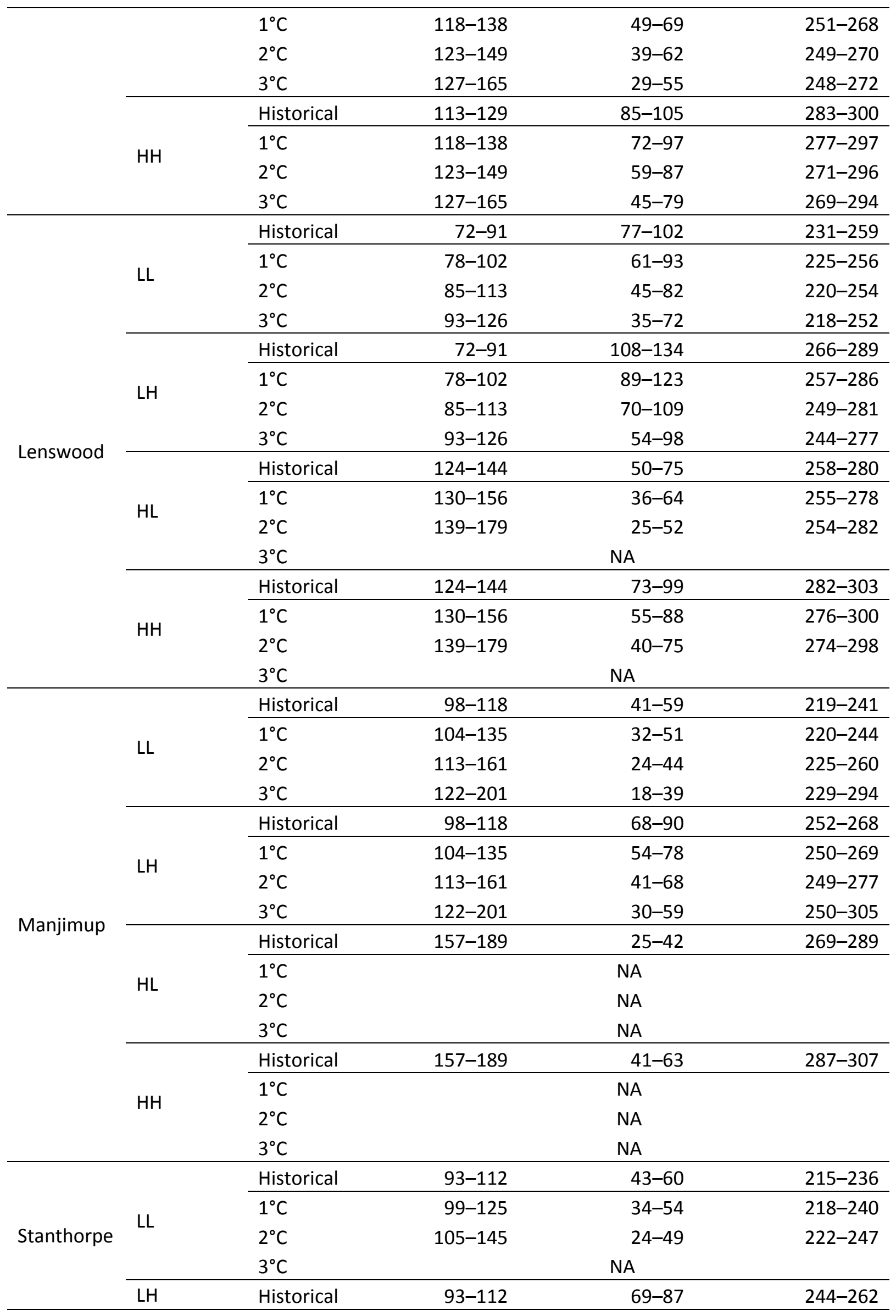




\begin{tabular}{|c|c|c|c|c|}
\hline & $1^{\circ} \mathrm{C}$ & 99-125 & $54-80$ & $243-261$ \\
\hline & $2^{\circ} \mathrm{C}$ & $105-145$ & $38-73$ & $244-262$ \\
\hline \multicolumn{5}{|c|}{$3^{\circ} \mathrm{C}$} \\
\hline \multirow{4}{*}{$\mathrm{HL}$} & Historical & $152-177$ & $22-38$ & $261-274$ \\
\hline & $1^{\circ} \mathrm{C}$ & & VA & \\
\hline & $2^{\circ} \mathrm{C}$ & & VA & \\
\hline & $3^{\circ} \mathrm{C}$ & & VA & \\
\hline \multirow{4}{*}{$\mathrm{HH}$} & Historical & $152-177$ & $36-56$ & $276-290$ \\
\hline & $1^{\circ} \mathrm{C}$ & & VA & \\
\hline & $2^{\circ} \mathrm{C}$ & & VA & \\
\hline & $3^{\circ} \mathrm{C}$ & & VA & \\
\hline
\end{tabular}

604

LL is low chill low heat; $\mathrm{LH}$ is low chill high heat; $\mathrm{HL}$ is high chill low heat; $\mathrm{HH}$ is high chill high heat

605 
LL
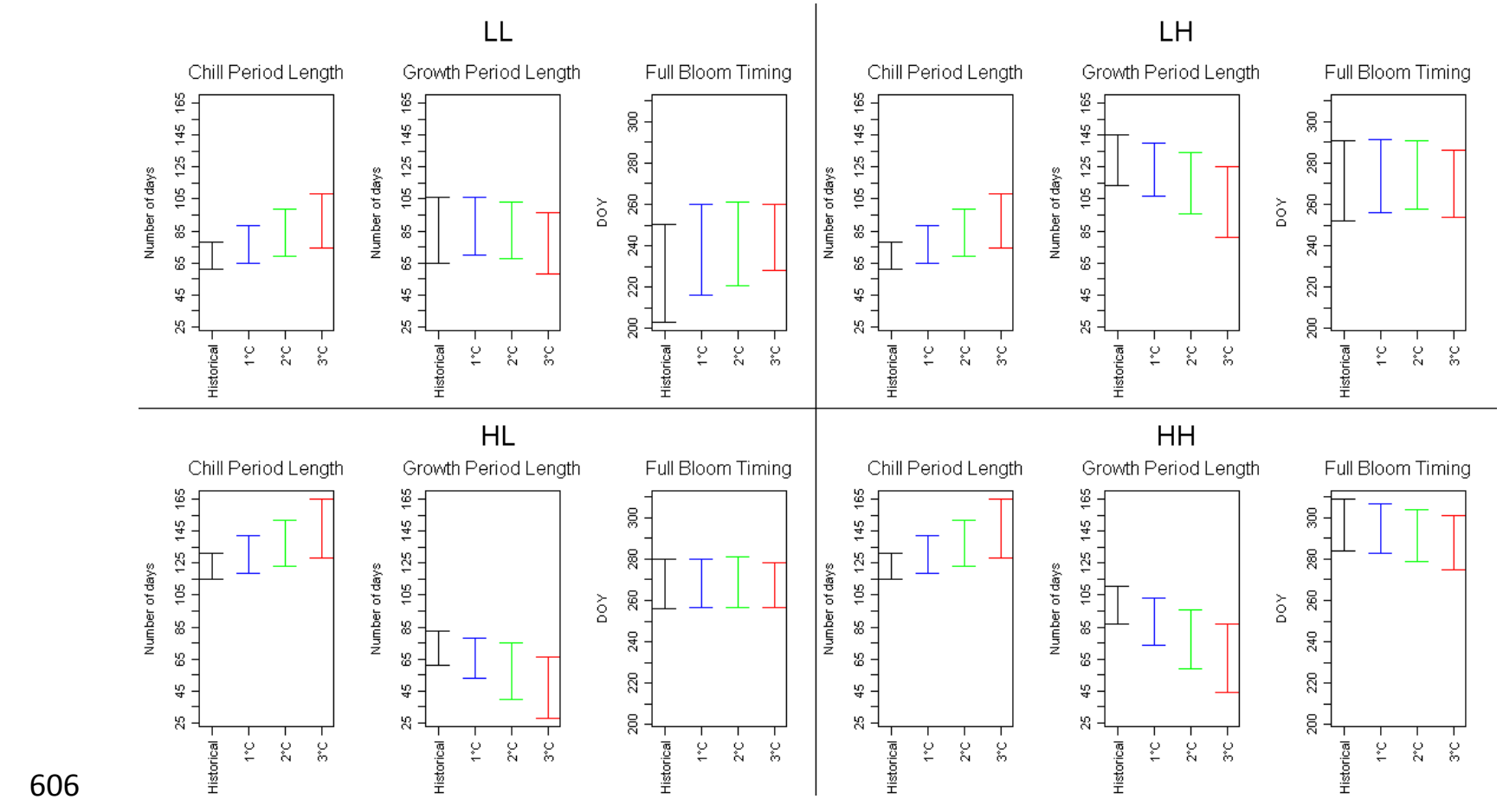

LH

607 


\section{Granny Smith Apple (Tatura)}
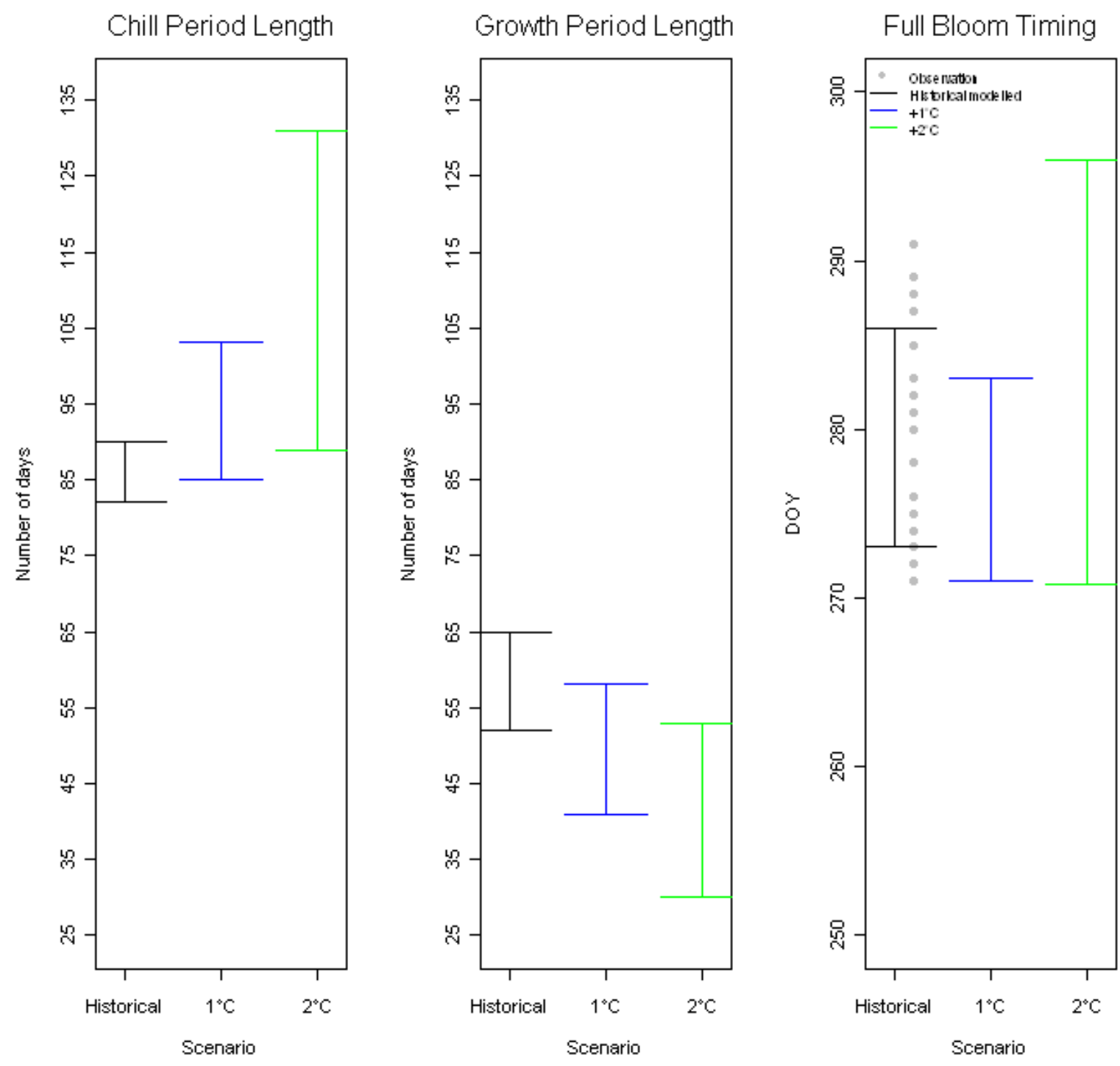

608 


\section{Granny Smith apple (Tatura)}

Springtime Warming

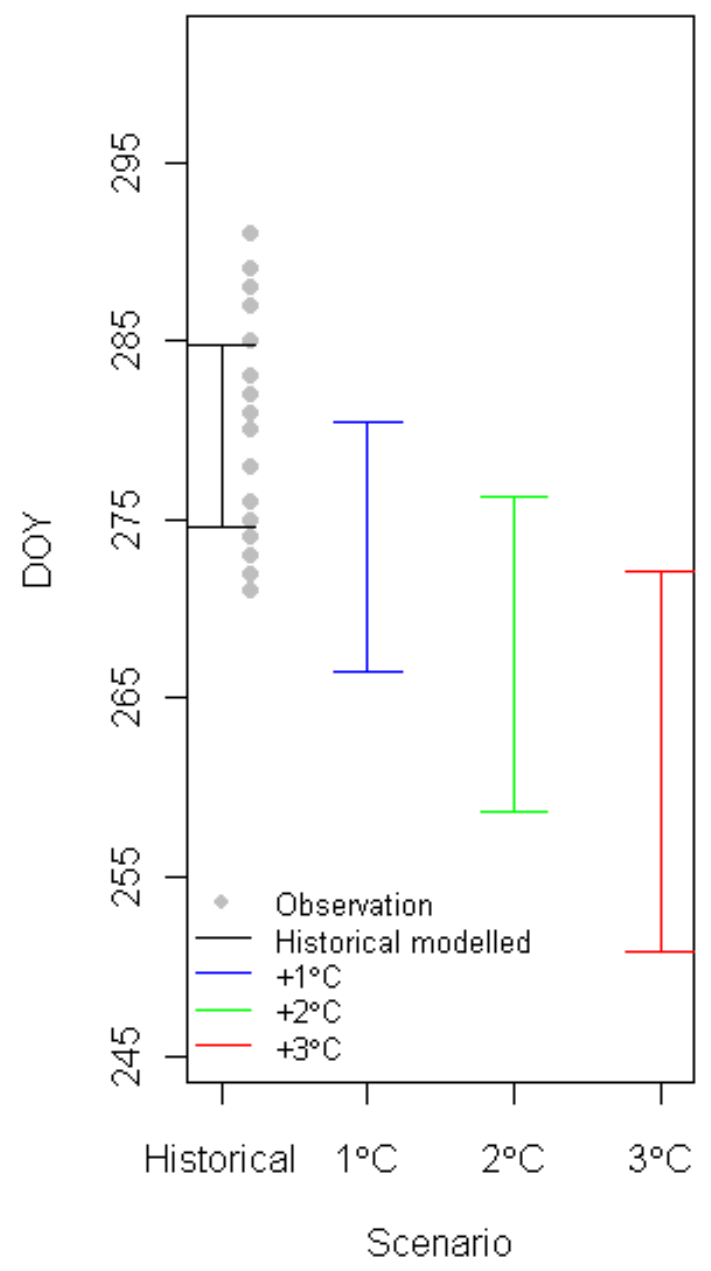

Sequential Chill-Growth

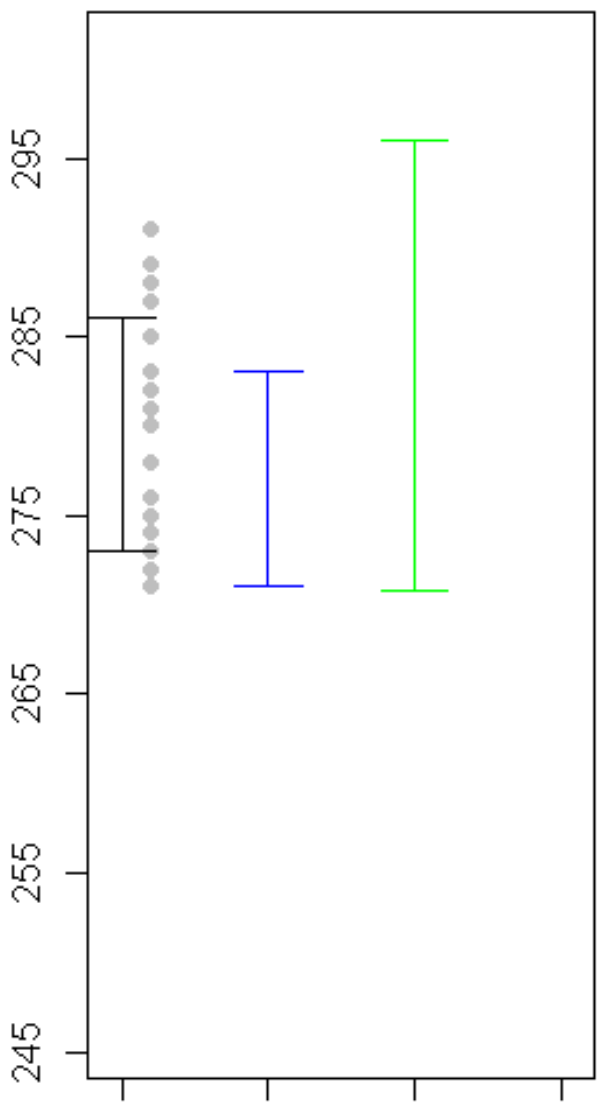

Historical $\quad 1^{\circ} \mathrm{C} \quad 2^{\circ} \mathrm{C} \quad 3^{\circ} \mathrm{C}$ 


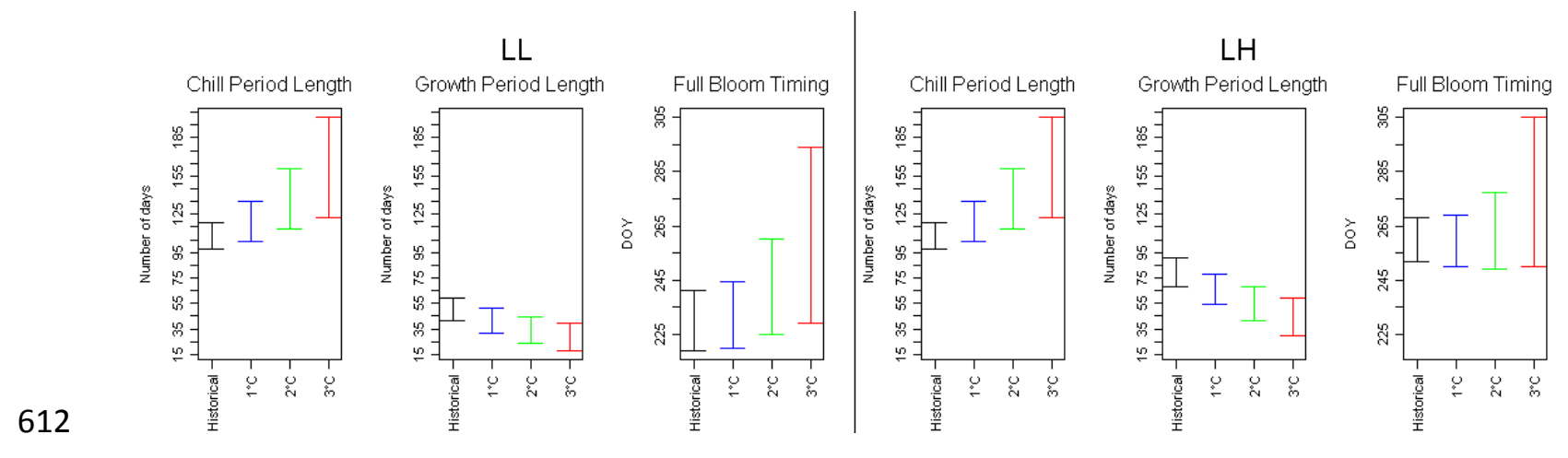

613 


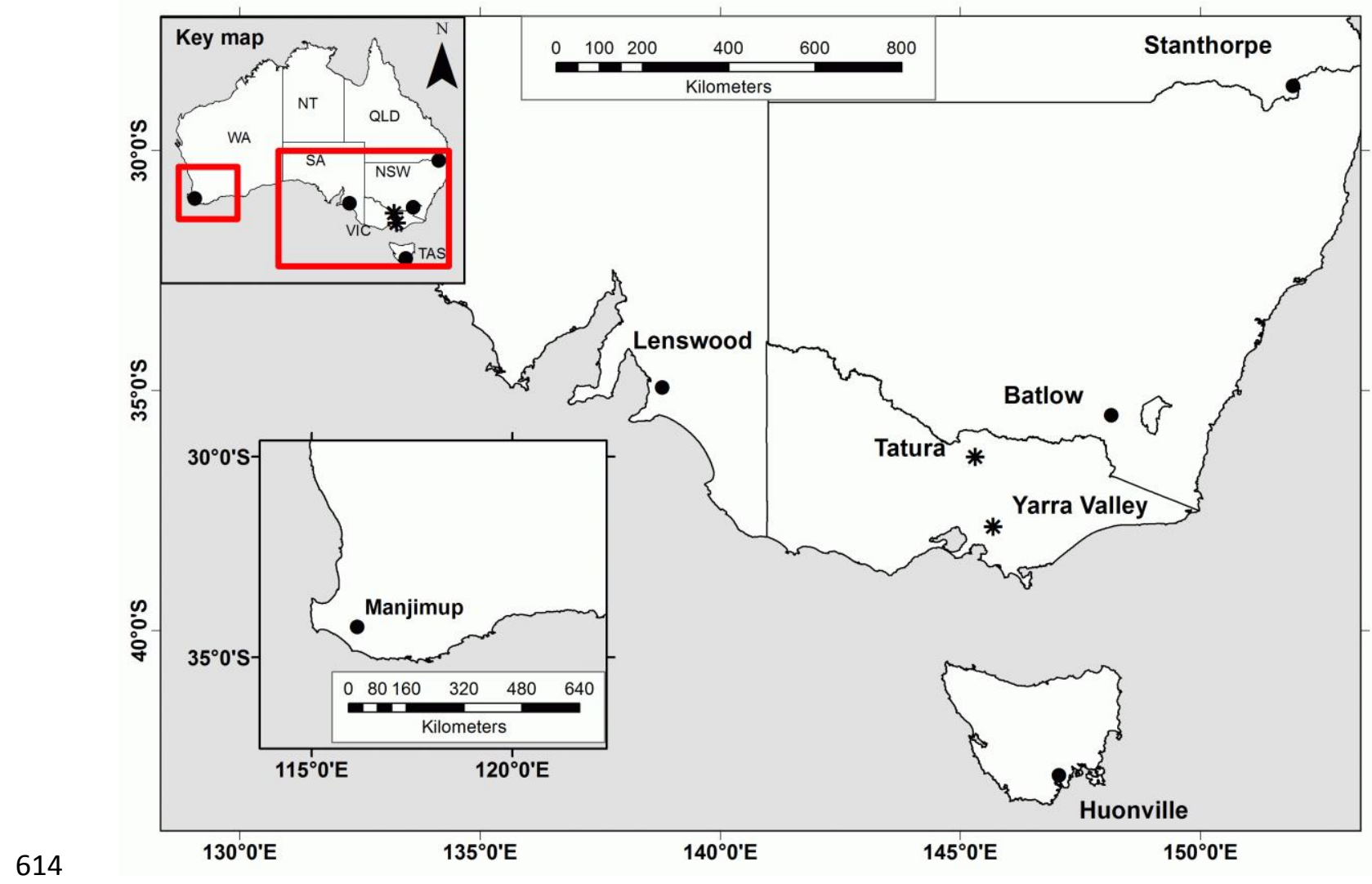




\section{University Library}

\section{- M M N E R VA A gateway to Melbourne's research publications}

Minerva Access is the Institutional Repository of The University of Melbourne

\section{Author/s:}

Darbyshire, R;Webb, L;Goodwin, I;Barlow, EWR

Title:

Challenges in predicting climate change impacts on pome fruit phenology

Date:

2014-08-01

Citation:

Darbyshire, R., Webb, L., Goodwin, I. \& Barlow, E. W. R. (2014). Challenges in predicting climate change impacts on pome fruit phenology. INTERNATIONAL JOURNAL OF BIOMETEOROLOGY, 58 (6), pp.1119-1133. https://doi.org/10.1007/s00484-013-0705-4.

Persistent Link:

http://hdl.handle.net/11343/283227 